Jurnal Keperawatan Silampari

Volume 2, Nomor 1, Desember 2018

e-ISSN : 2581-1975

p-ISSN : 2597-7482

DOI: https://doi.org/10.31539/jks.v2i1.14

\title{
HOME VISIT BERBASIS SISTEM INFORMASI MANAJEMEN TELENURSING
}

\author{
Padila $^{1}$, Liza Fitri Lina ${ }^{2}$, Henni Febriawati ${ }^{3}$, Bintang Agustina ${ }^{4}$, Riska Yanuarti ${ }^{5}$ \\ Program Studi Ilmu Keperawatan, Universitas Muhammadiyah Bengkulu ${ }^{1,2}$ \\ Program Studi Kesehatan Masyarakat, Universitas Muhammadiyah Bengkulu ${ }^{3,4,5}$ \\ padila@umb.co.id ${ }^{1}$
}

\begin{abstract}
ABSTRAK
Penelitian ini bertujuan menganalisis gambaran pengadaan sistem informasi manajemen keperawatan home visit telenursing di RSUD. Dr. M. Yunus Bengkulu. Desain penelitian yang peneliti gunakan memodifikasi teori penelitian $(\mathrm{R})$ dan pengembangan (D). Pengembangan teknologi telenursing berbasis teknologi BAN (body area network) dapat memberikan hasil monitoring secara real time dan terkoneksi dengan transmisi WSN (wireless sensor network) melalui integrasi dengan deviceenduser (laptop) yang secara desain dan implementasi dapat digunakan didaerah pedesaan dan terpencil. Hasil penelitian terdapat rancangan sistem program yang memiliki keunggulan mampu digunakan untuk mengirim data medis pasien, keluhan utama, tipe penyakit yang dirasakannya (ringan, sedang dan berat), visualisasi data secara image, sound dan text, bahkan video dapat digunakan sebagai alat detektor kesehatan pasien berbasis digital melalui video mail, dan riwayat kesehatan keluarga dengan teknik multimedia medical records yang terkoneksi dengan pusat layanan kesehatan RSUD. Dr. M. Yunus Bengkulu. Penelitian langsung diujicobakan kepada perawat untuk memperoleh pemahaman perawat dalam penggunaan telenursing. Simpulan, yang didapat dari penelitian ini adalah antusiasme perawat dalam menerima tantangan baru dalam memberikan pelayanan telenursing sangat tinggi, hal tersebut dapat berdampak pada kemampuan meningkatkan komunikasi yang efektif antara perawat dan pasien.
\end{abstract}

Kata Kunci: Home Visit Telenursing, Pengembangan, SIM

\section{ABSTRACT}

This study aims to analyze the description of procurement of nursing home information management systems for telenursing home visits at hospitals. Dr. M. Yunus Bengkulu. The research design that researchers use modifies the research theory $(R)$ and development (D). Development of telenursing technology based on BAN technology (body area network) can provide monitoring results in real time and connected with WSN (wireless sensor network) transmission through integration with deviceendusers (laptops) which in design and implementation can be used in rural and remote areas. The results of the study there is a system design program that has the advantage of being able to be used to send medical data of patients, the main complaints, the type of disease they feel (mild, moderate and severe), visualization of data in image, sound and text, even video can be used as a detector for patient health digital based via video mail, and family health history with multimedia medical records techniques that are connected to the hospital health care center. Dr. M. Yunus Bengkulu. The research was 
directly tested on nurses to gain nurses' understanding in using telenursing. Conclusions, which are obtained from this study are the enthusiasm of nurses in accepting new challenges in providing telenursing services is very high, it can have an impact on the ability to improve effective communication between nurses and patients.

Keywords: Home Visit Telenursing, Development, SIM

\section{PENDAHULUAN}

Saat ini dunia keperawatan semakin berkembang. Perawat dianggap sebagai salah satu profesi kesehatan yang harus dilibatkan dalam pencapaian tujuan pembangunan kesehatan baik didunia maupun di Indonesia. Salah satu tujuan pembangunan kesehatan di Indonesia adalah pemerataan pelayanan kesehatan ke seluruh daerah di Indonesia (Riskesdas, Balitbangkes, dan Kemenkes RI, 2016).

Teknologi informasi yang terus berkembang sekarang ini harus dicermati oleh dunia kesehatan khususnya dunia keperawatan untuk membantu menjawab permasalahan kesehatan yang ada. Semakin berkembangnya teknologi informasi merupakan suatu peluang untuk meningkatkan kualitas asuhan keperawatan dan meningkatkan jangkauan pelayanan keperawatan bagi masyarakat di seluruh Indonesia, termasuk masyarakat di daerah yang terpencil dan jauh (rural area). Salah satu teknologi keperawatan yang terus berkembang adalah telehealth nursing atau tele nursing (Kawaguchi et. all. 2004, Scotia, 2014).

Telenursing adalah upaya penggunaan teknologi informasi dalam memberikan pelayanan keperawatan dimana ada jarak secara fisik yang jauh antara perawat dan pasien, atau antar perawat. Telenursing merupakan bagian dari telehealth atau telemedicine dan beberapa bagian terkait dengan aplikasi bidang medis dan nonmedis seperti telediagnosis, telekonsultasi dan telemonitoring (Durrani, Khoja, 2009).

Praktik telenursing dapat diaplikasikan dalam berbagai setting area keperawatan, dan dapat berbentuk ambulatory care, call centers, home visit telenursing, bagian rawat jalan dan bagian kegawatdaruratan. Telenursing juga dapat digunakan dalam ragam yang sangat bervariasi, meliputi: via telepon (landline dan telepon seluler), personaldigital assistants (PDAs), mesinfaksimili, internet by email, video dan audioconferencing, teleradiologi, sistem informasi komputer bahkan melalui telerobotics (Scotia, 2014).

Bentuk-bentuk telenursing dapat berupa triage telenursing, call-centerservices, konsultasi melalui securee mail messaging system, konseling melalui hotlineservice, audio atau videoconferencing antara pasien dengan petugas kesehatan atau dengan sesama petugas kesehatan, discharge planning telenursing, home-visittelenursing dan pengembangan websites sebagai pusat informasi dan real-time counseling padapasien (CNA, 2005; Centrefor E-Health Nursing, 2006; Canadian Nursing Informatics Association, 2015).

Home visit telenursing belum dikembangkan secara optimal di Indonesia, apalagi di Provinsi Bengkulu, mengingat Bengkulu adalah area rawan yang berisiko tinggi gempa, longsor, banjir serta tsunami karena sepanjang kota bengkulu dikelilingi oleh pantai, sehingga home visit telenursing ini sangat bermanfaat dan berguna dalam layanan akses kesehatan guna menurunkan angka hospitalisasi yang tidak terencana dan mengurangi stress keluarga. Menurut Cady, et al. (2009) salah satu tujuan telehealth atau home visit telenursing adalah untuk meningkatkan akses yang lebih komprehensif dan meningkatkan kualitas layanan kesehatan. Dimana pasien dengan mudah 
memberikan kabar tentang kondisi kesehatannya setelah proses pemulihan ataupun saat mula terkena sakitnya kepada perawat yang telah dipercaya dalam memberikan pelayanan kepada pasiennya.

Durrani dan Khoja (2009) melakukan systematic review untuk melihat perkembangan telehealth dan telenursing di wilayah Asia. Berdasarkan studi yang dilakukan mereka didapatkan data bahwa: Jepang merupakan negara yang paling banyak melakukan telehealthnursing, kemudian India dan HongKong. Telenursing dilakukan di RS, pusat layanan kesehatan primer, rawat jalan, home-visit, dan hospicecare. Di Asia metode yang digunakan dalam telehealthnursing sebagian besar menggunakan non-realtime consultation dan video conferencing. Teknologi yang paling banyak digunakan di Asia adalah line ISDN, saluran telepon konvensional, koneksi satelit broadband, mobile phone atau wireless. Berdasarkan hasil penelitian tersebut mendapatkan bahwa $40 \%$ penelitian tentang aplikasi telenursing mengindikasikan adanya peningkatan dalam kualitas layanan yang diberikan dan pengguna telenursing menyatakan puas.

Studi etnographi oleh O'Connor, et al (2014) dengan judul Health professional's response to the introduction of a home telehealth services, mendapatkan data bahwa petugas kesehatan mendapatkan tantangan baru untuk mengintegrasikan kemajuan teknologi dalam pelayanan keperawatan yang diberikan kepada pasiennya.

Menurut Cady, et al. (2009) salah satu tujuan telehealth atau home visit telenursing adalah untuk meningkatkan akses yang lebih komprehensif dan meningkatkan kualitas layanan kesehatan. Dimana pasien dengan mudah memberikan kabar tentang kondisi kesehatannya setelah proses pemulihan ataupun saat mula terkena sakitnya kepada perawat, yang telah dipercaya dalam memberikan pelayanan kepada pasiennya.

Untuk itulah home visit telenursing pada sistem informasi manajemen keperawatan di RSUD. Dr. M. Yunus Bengkulu menjadi sangat penting dan sangat bermanfaat tidak hanya buat perawat, tetapi juga memberikan kemudahan kepada setiap pasien dalam mengakses pelayanan kesehatan guna meningkatkan derajat kesehatan masyarakat serta akan menambah income tambahan bagi RS tersebut. Adapun tujuan penelitian ini adalah untuk membuat pengembangan model sistem informasi manajemen keperawatan berbasis home visit telenursing di RSUD Dr. M.Yunus Kota Bengkulu.

\section{METODE PENELITIAN}

Jenis penelitian yang digunakan adalah penelitian pengembangan, diartikan sebagai "kegiatan pengumpulan, pengolahan, analisis, dan penyajian data yang dilakukan secara sistematis dan objektif yang disertai dengan kegiatan mengembangkan sebuah produk untuk memecahkan suatu persoalan yang dihadapi (Borg, Gall, 1983).

Secara garis besar penelitian dan pengembangan diawali dengan penelitianpenelitian dalam skala kecil yang bisa dalam bentuk pengumpulan data terkait dengan persoalan yang dihadapi dan ingin dipecahkan. Hasil penelitian awal dijadikan dasar untuk melakukan pengembangan sebuah produk (draf), pada proses pengembangan peneliti tetap melakukan pengataman, terutama pada proses uji coba produk. Hasil uji coba kemudian dianalis dan direvisi kemudian disajikan dalam bentuk data hasil penelitian dan pengembangan.

Desain penelitian yang peneliti gunakan memodifikasi teori penelitian dan pengembangan oleh Borg dan Gall (1983) dimana tahapan tersebut dapat digambarkan sebagai berikut: 


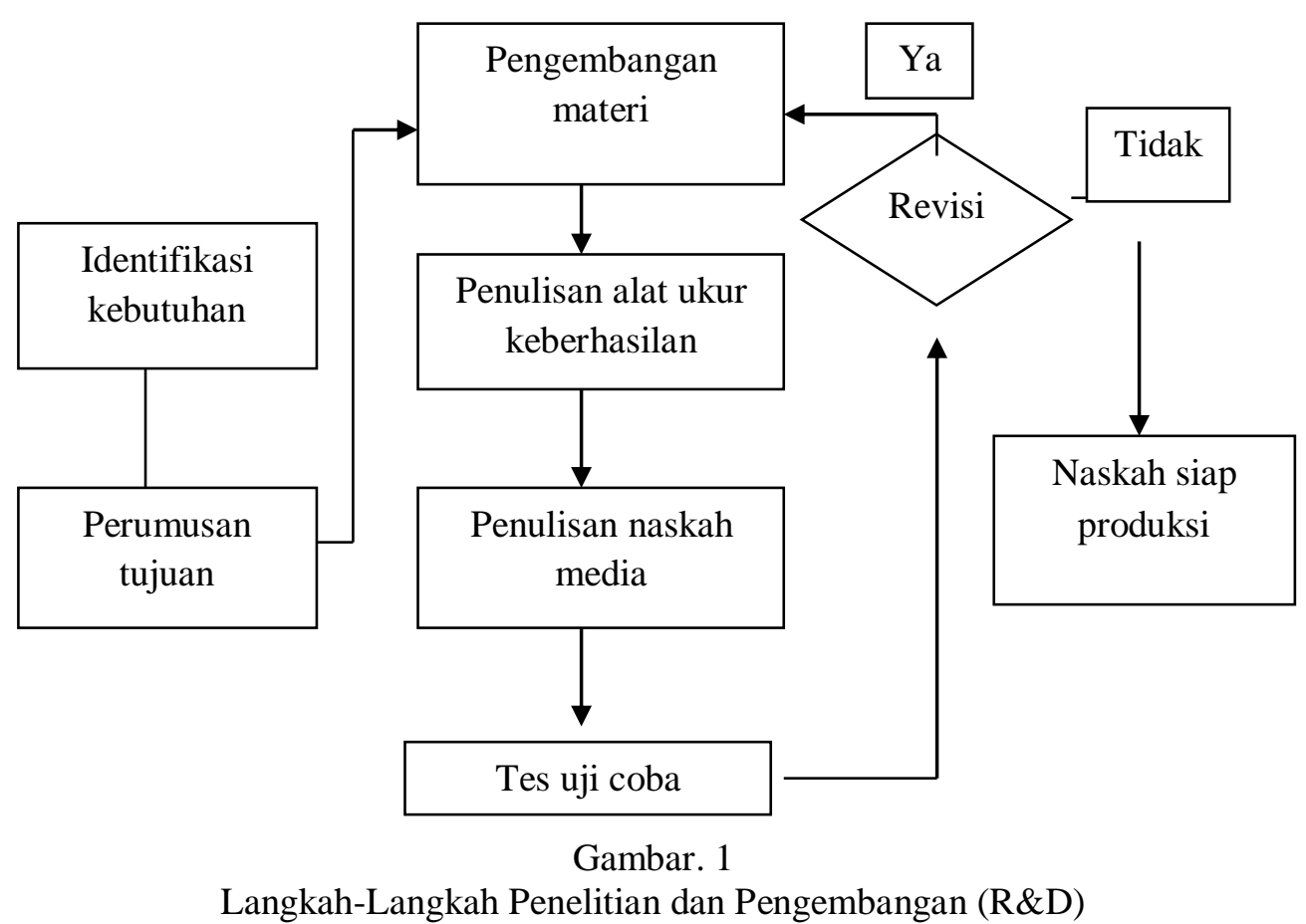

\section{HASIL PENELITIAN \\ Analisis Kebutuhan}

Analisis kebutuhan yang dilakukan meliputi pengumpulan data tentang pengelolaan komponen rumah sakit, penggunaan dan pemanfaatan teknologi informasi, serta pelaksanaan sistem informasi manajemen keperawatan berbasis homevisite telenursing di RSUD Dr. M. Yunus Bengkulu. Kemudian peneliti melakukan wawancara kepada Ka. Subbag data dan informasi serta perawat ruang inap untuk mendapatkan data tentang pengelolaan sistem informasi manajemen keperawatan.

Pengelolaan data pasien sudah terdokumentasi secara elektronik, pengelolaan tenaga keperawatan masih menggunakan cara manual yaitu terpampang dipapan informasi disetiap ruang rawat inap, penggunaan komputer dalam pengelolaan data asuhan keperawatan dan arsip dokumentasi sudah menggunakan komputer atau laptop, penggunaan jaringan internet sudah menggunakan jaringan internet (modem atau wifi) dalam pengelolaan data rumah sakit, dengan adanya jaringan internet pihak rumah sakit akan lebih mudahdalammengakses tentang informasi-informasi yang berkaitan dengan peningkatan mutu rumah sakit dan juga rumah sakit akan lebih mudah untuk memberikan laporan mengenai perkambangan rumah sakit kepada masyarakat". Pengelolaan pelayanan belum mengarah pada homevisite telenursing, pelayanan masih manual yakni belum menggunakan jasa elektronik sebagai komunikasi. Rumah sakit sudah memiliki dan menggunakan email dalam pengelolaan data dan sudah menggunakan webbinar jika para dokter ingin mengikuti seminar/workshop jarak jauh. 


\section{Perencanaan Sistem}

Berdasarkan analisis kebutuhan, maka sangatlah perlu dilakukan pengembangan SIM keperawatan homevisite telenursing di RSUD Dr. M.Yunus Bengkulu. Adapun penjelasan secara detail perencanaan sistem sebagai berikut:

\section{Menu Home}

Menu home merupakan tampilan awal yang berisikan tulisan "telenursing in home visite service system" disampingnya terdapat form username dan password, dan form login berfungsi untuk masuk kehalaman khusus admin, dan pengguna telenursing system (perawat, dokter, nutrisionist, apoteker dan masyarakat).

\section{Menu Banner}

Menu banner dibawah form login terdapat slide show yang berisi gambar yang sudah diedit yang tampil bergantian, di bagian isi terdapat berita dan informasi berkaitan dengan telenursing, di bagian footer (bawah) terdapat kontak informasi.

\section{Menu Halaman Home Admin dan Pengguna}

Menu halaman home admin dan pengguna berikut dengan menu-menunya yang meliputi: menu past data, vital sign, riwayat keluarga, input email, input video mail, health subcenter, menu pembayaran, menu berita, menu artikel, menu pemakai, menu logout.

\section{Rancangan SIM Homevisite Telenursing}

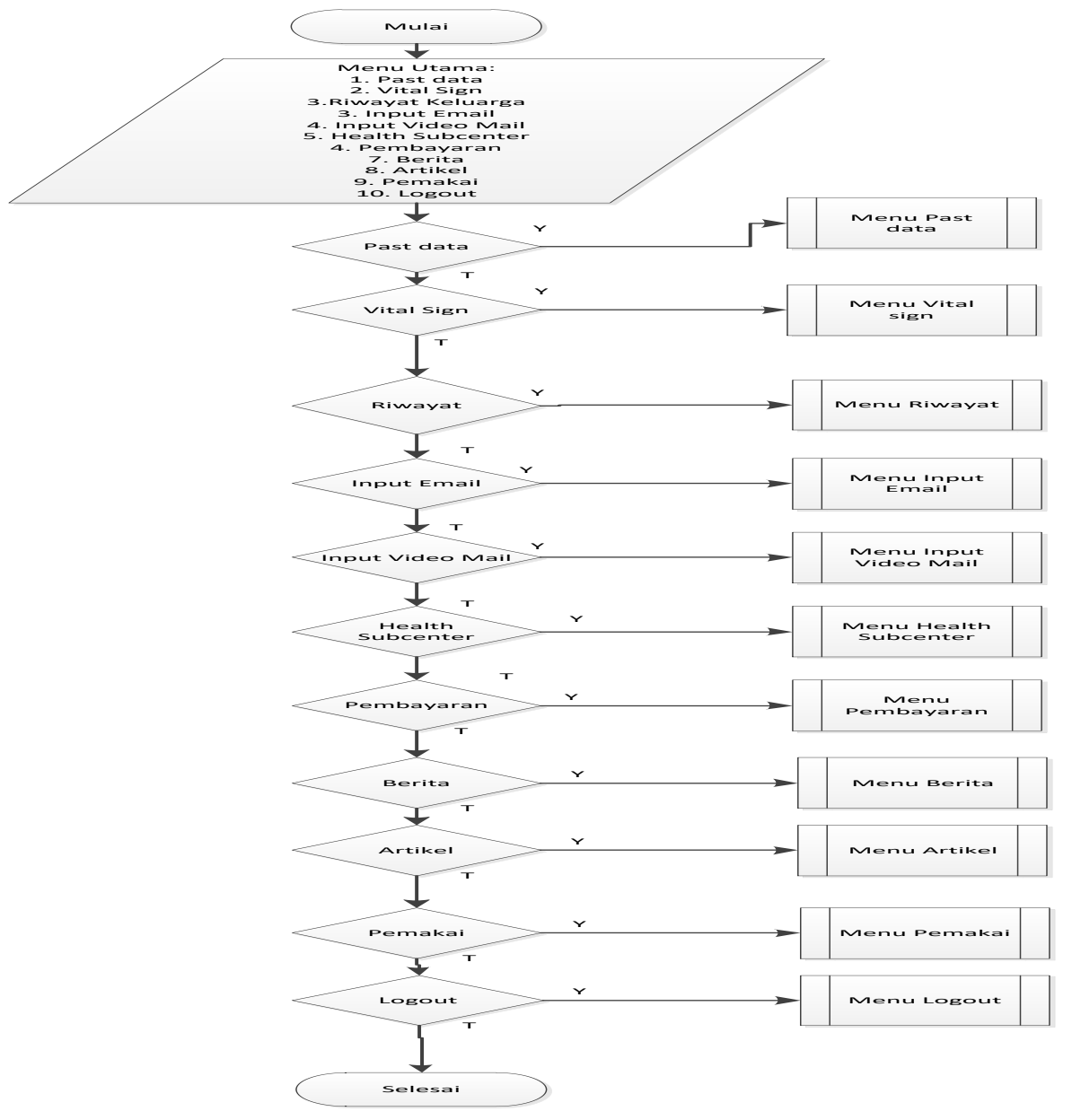


Setelah melakukan login dengan username dan password, maka admin RS dan Pengguna layanan home visite teleunursing dapat masuk ke komponen menu utama yakni meliputi; menu home, menu past data, vital sign, riwayat penyakit, input email, input video mail, health subcenter, pembayaran, berita, artikel, pemakai, logut dan menu keluar.

\section{Pengembangan SIM Database Rumah Sakit} Menu Halaman Depan (Homepage)

Halaman depan (homepage) adalah tampilan yang muncul saat pertama kali kita buka link telenursing. Pada halaman depan ini berisi informasi tentang telenursing, berita yang muncul saat ini, artikel tentang telenursing, footer yang berisi kontak dan form login untuk masuk ke dalam sistem sebagai pasien atau sebagai admin.

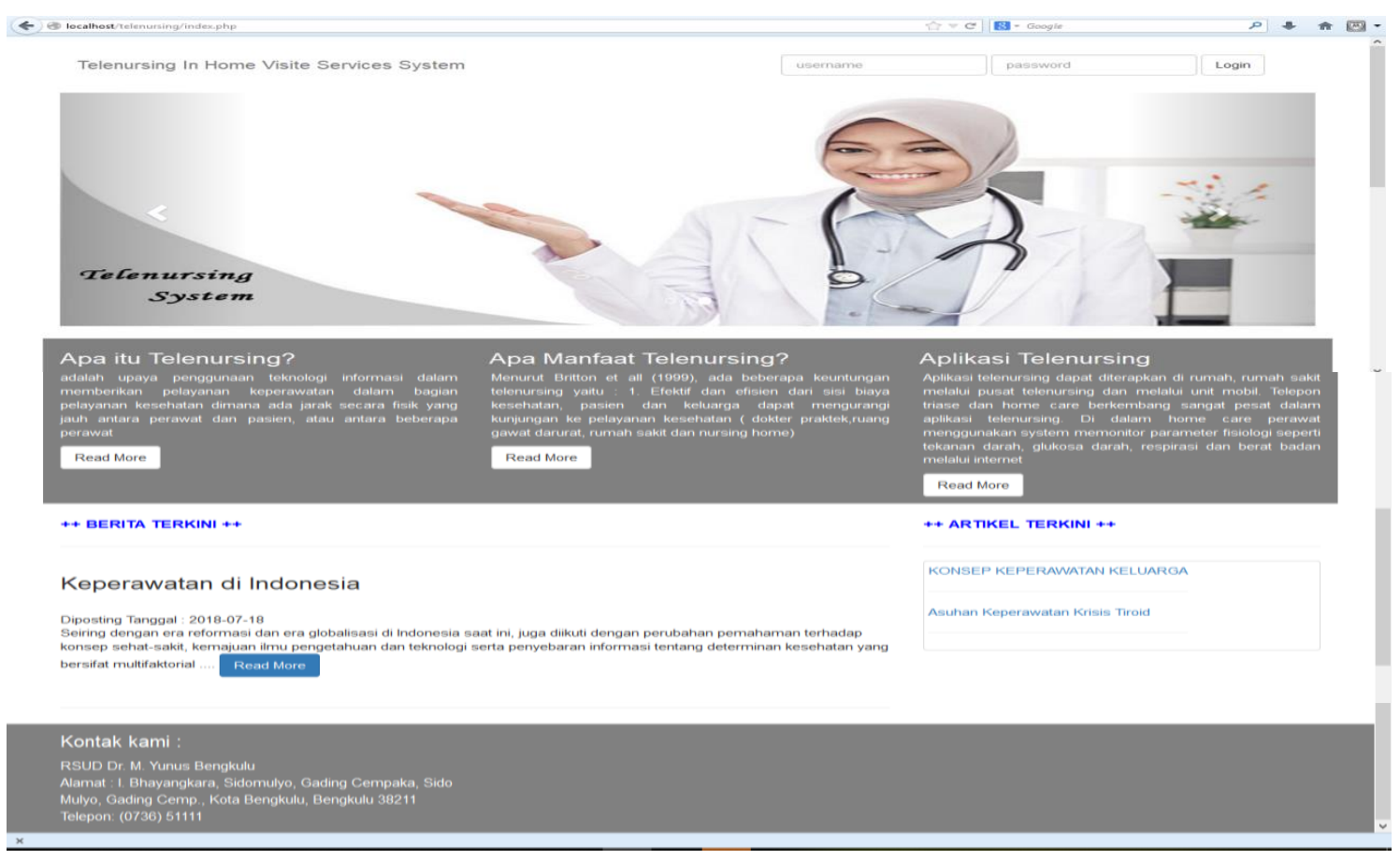

\section{Form login}

Form login terdapat di halaman depan, tepatnya berada di pojok kanan atas

username password Login

Kita diminta memasukkan username dan password. Untuk pasien username dan password akan diberikan oleh admin system. Melalui form login ini kita bisa masuk ke halaman admin system dan halaman khusus pasien yang terdaftar dalam program telenursing.

\section{Halaman Admin System}

Halaman admin sistem adalah halaman yang berisi semua hal yang berkaitan dengan system. Baik yang berhubungan dengan fungsi utama system ataupun fungsi penunjangnya. Adapun menu-menu yang terdapat dalam halaman admin meliputi 1) menu past data, 2) menu vital sign, 3) menu riwayat keluarga, 4) menu input email, 5) 
menu input video mail, 6) menu health subcenter, 7) menu pembayaran, 8) menu berita, 9) menu artikel, dan 10) menu pemakai. Berikut tampilan halaman admin system:

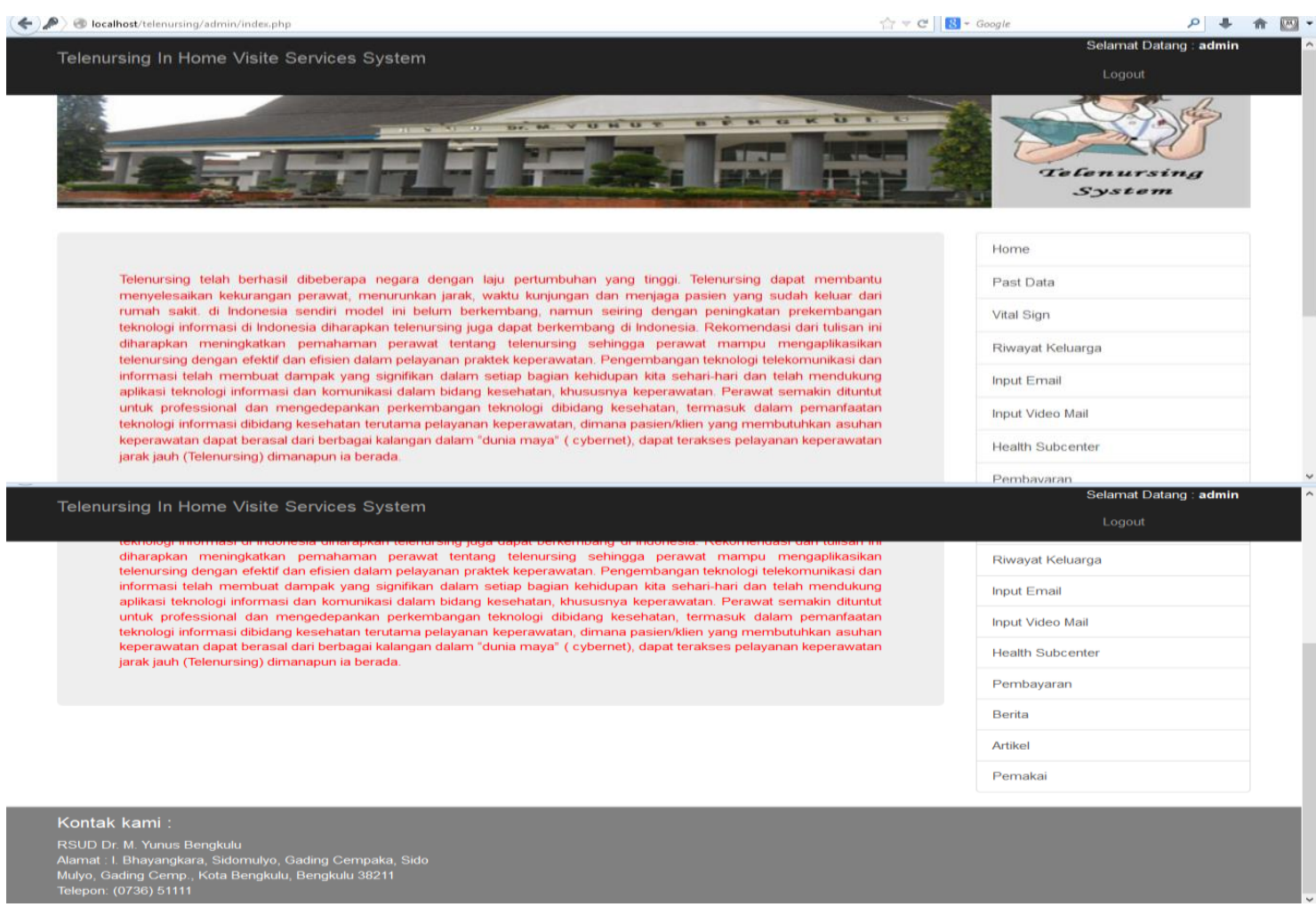

\section{Menu Past Data}

Pada menu past data, berisi data-data pasien yang telah mendaftar dalam sistem telenursing.

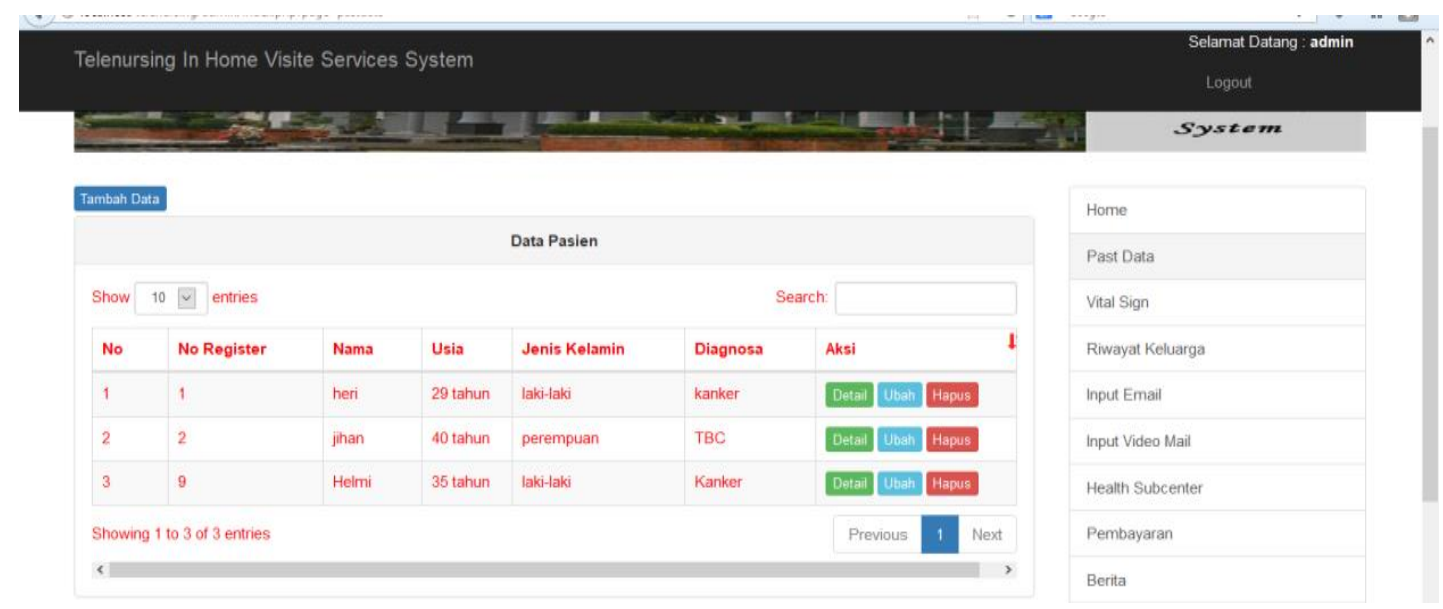

Pada menu past data terdapat aksi tambah data, detail, ubah dan hapus data. Adapun data berisi data noregister, nama, usia, jenis kelamin, alamat, no telepon, pekerjaan, pendidikan, diagnosis medis dan nama obat yang dikonsumsi. Berikut tampilan tambah data, detail dan ubah. 


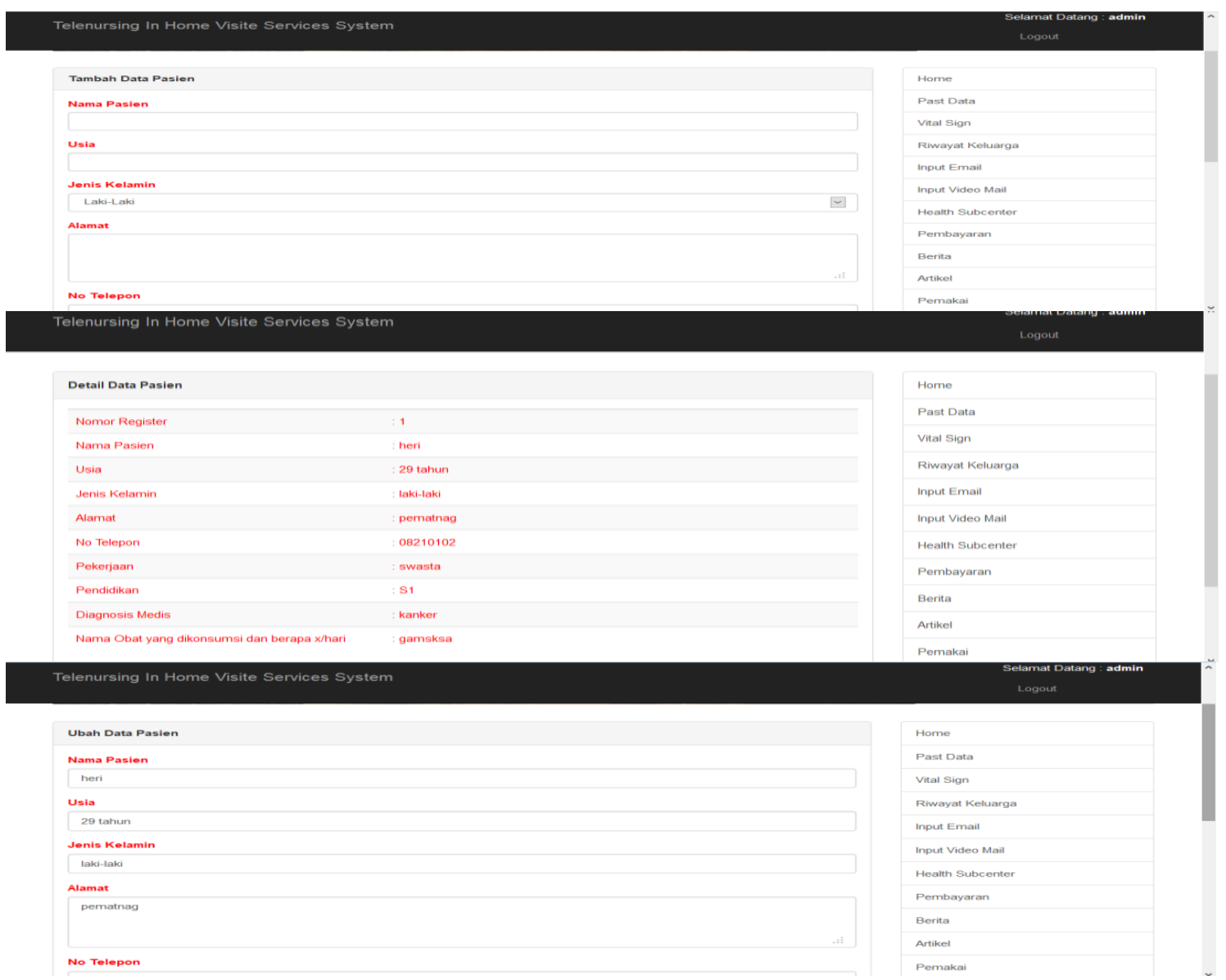

\section{Menu Vital Sign}

Menu vital sign berisi data yang berkaitan dengan kondisi pasien yang terdiri dari tekanan darah, denyut nadi, pernafasan, dan suhu badan. Di dalamnya terdapat aksi tambah data, ubah data dan hapus data. Berikut tampilan tambah data, ubah data dan tampilan datanya.

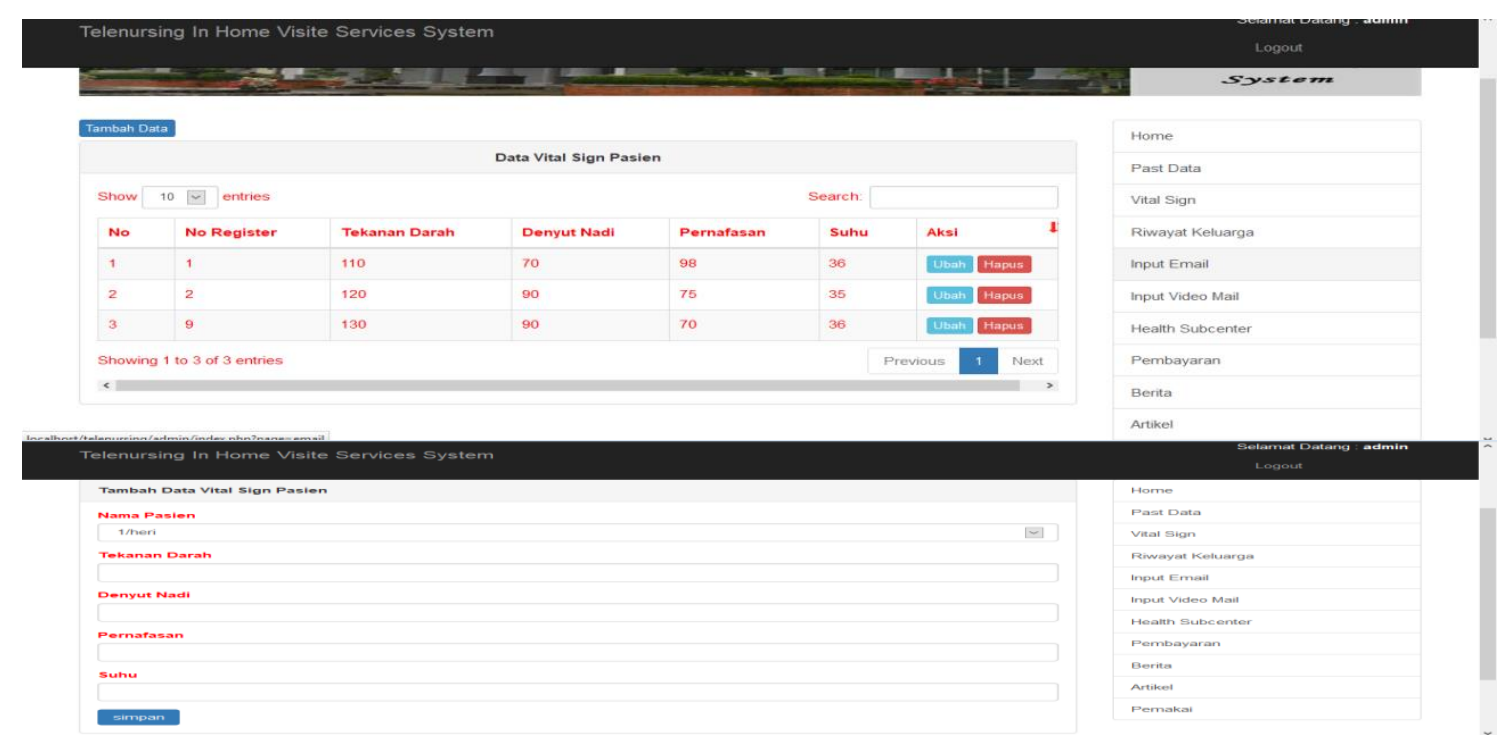




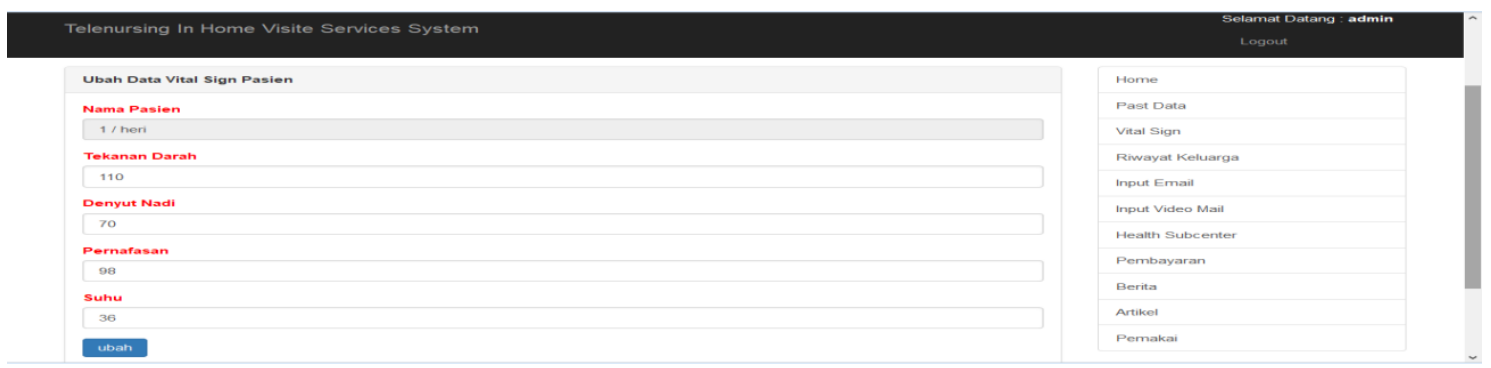

\section{Menu Riwayat Keluarga}

Pada menu riwayat keluarga berisi informasi tentang keluarga yang memiliki riwayat penyakit yang sama dengan pasien. Terdapat aksi tambah data, ubah data dan hapus data. Data yang terdapat di dalamnya adalah no register pasien dan riwayat keluarga. Berikut tampilan tambah data dan ubah data.

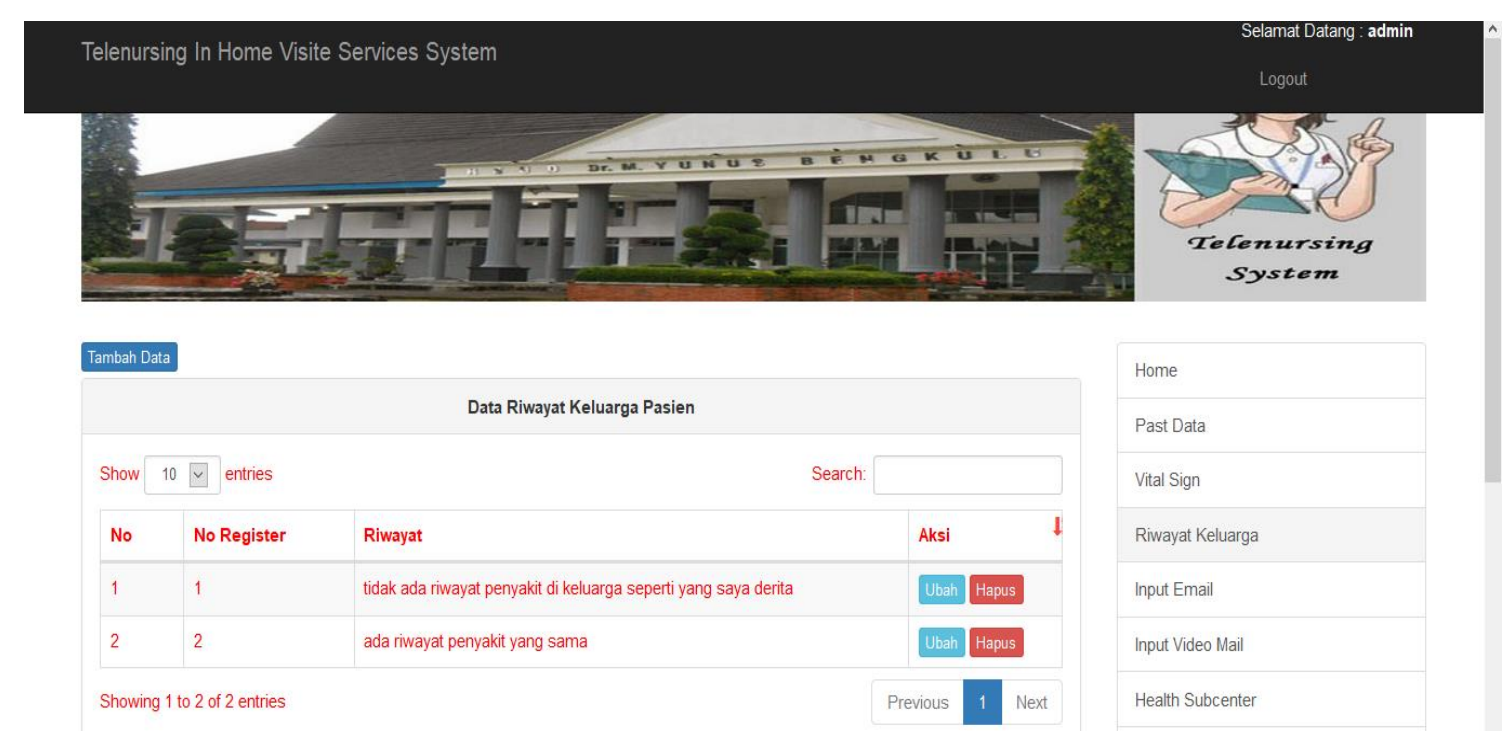

\section{Menu Input Email}

Menu input email berisi keluhan pasien terdiri dari keluhan pasien, status sakit ringan sedang atau berat, tekanan darah, denyut nadi, pernafasan dan suhu. Berikut tampilan tambah data, dan ubah data.

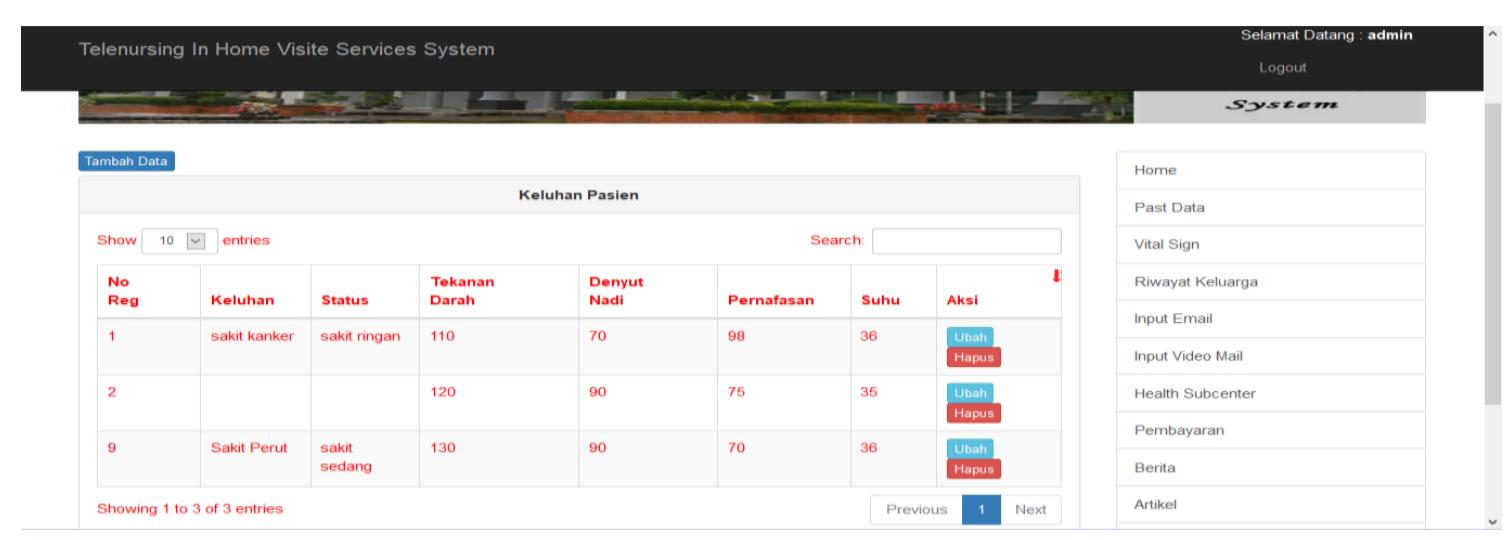




\section{Menu Input Video Mail}

Pada menu input video mail, terdapat form untuk melihat dan tambah video keadaan pasien yang akan didiagnosa. Di admin bisa melihat video pasien dan menambah video pasien. Berikut tampilannya.

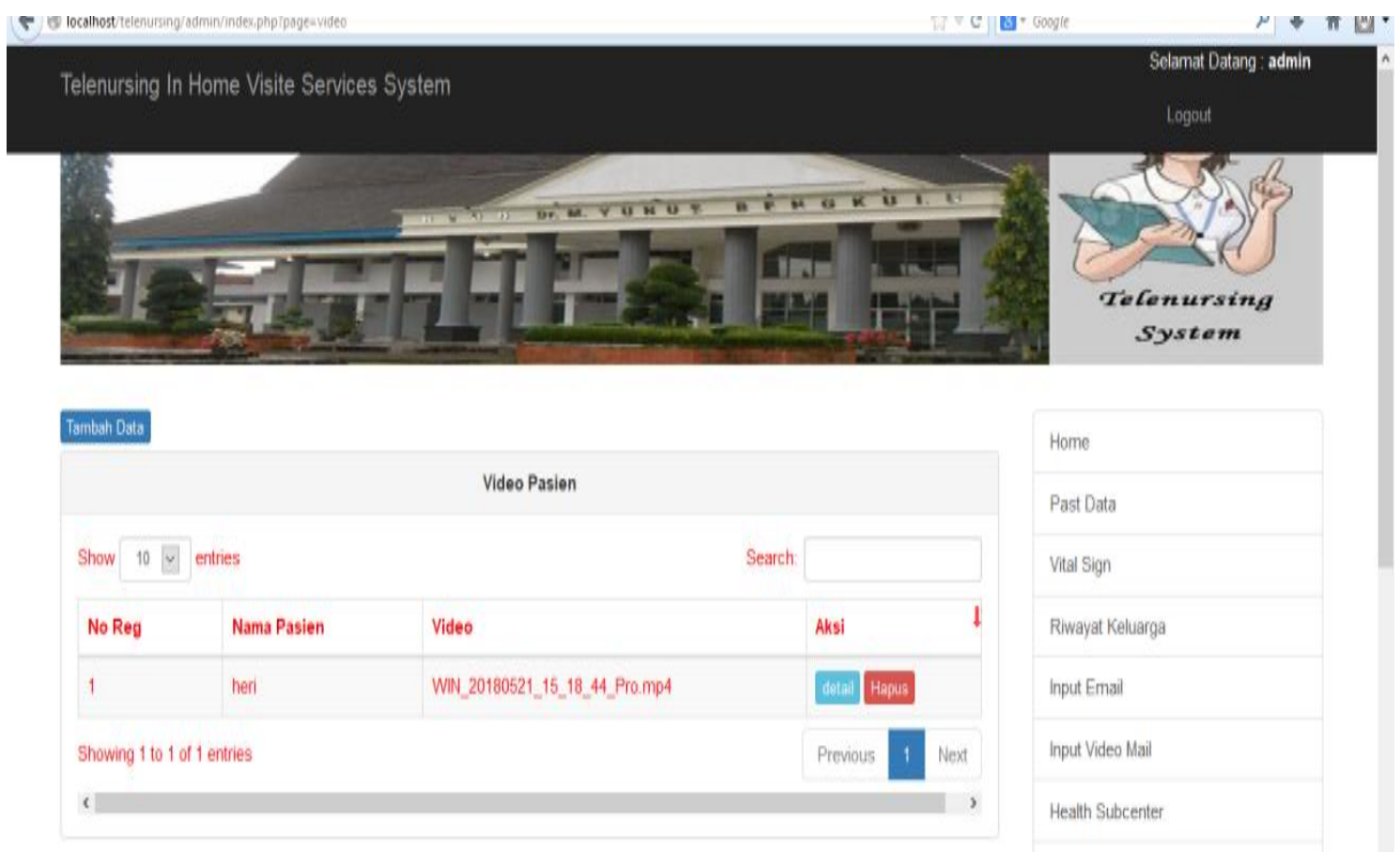

Untuk menambahkan video klik tombol browse, maka akan tampil kotak dialog untuk mencari file yang akan ditambahkan.

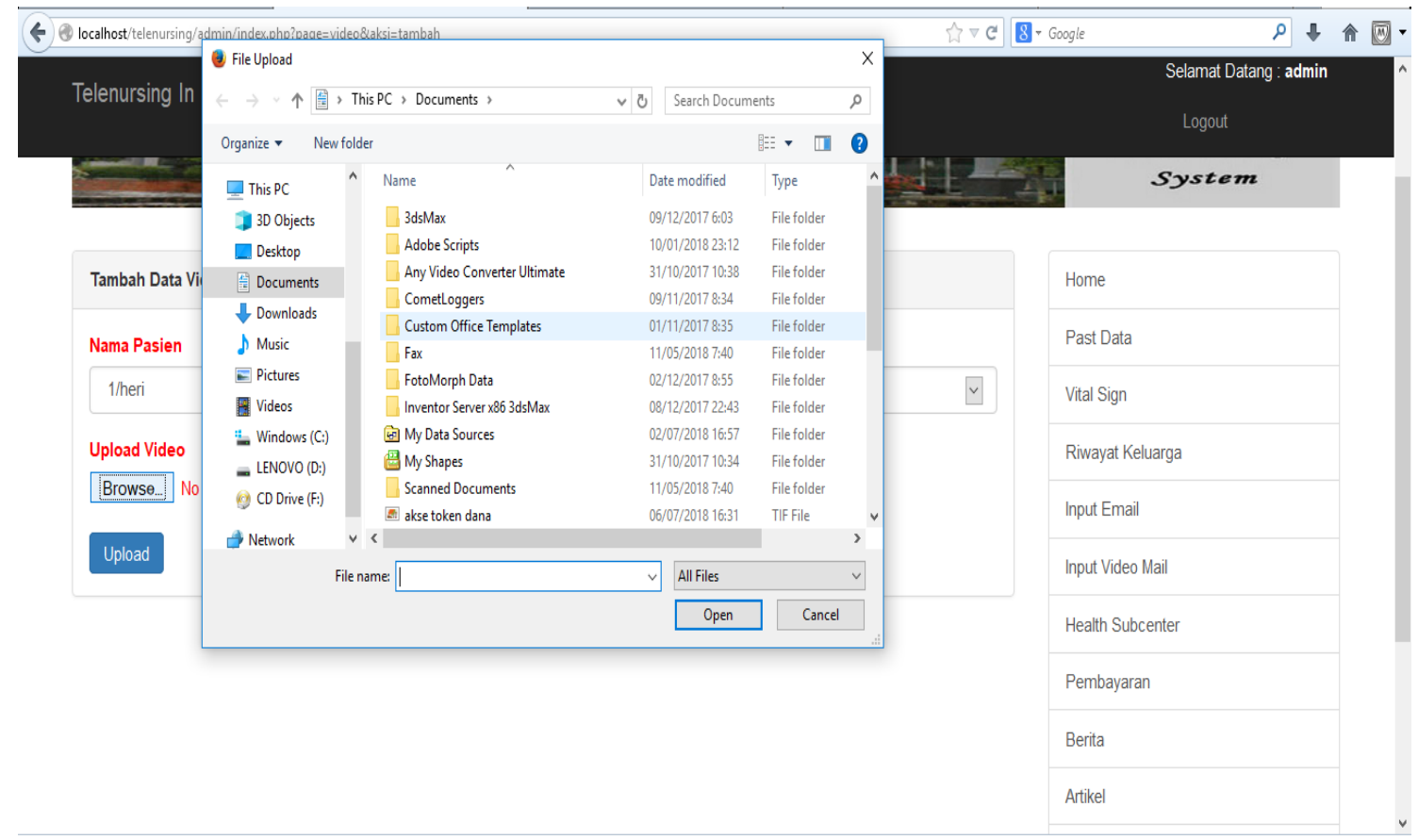


Berikut detail video, kita bisa melihat file video yang akan dibuka.

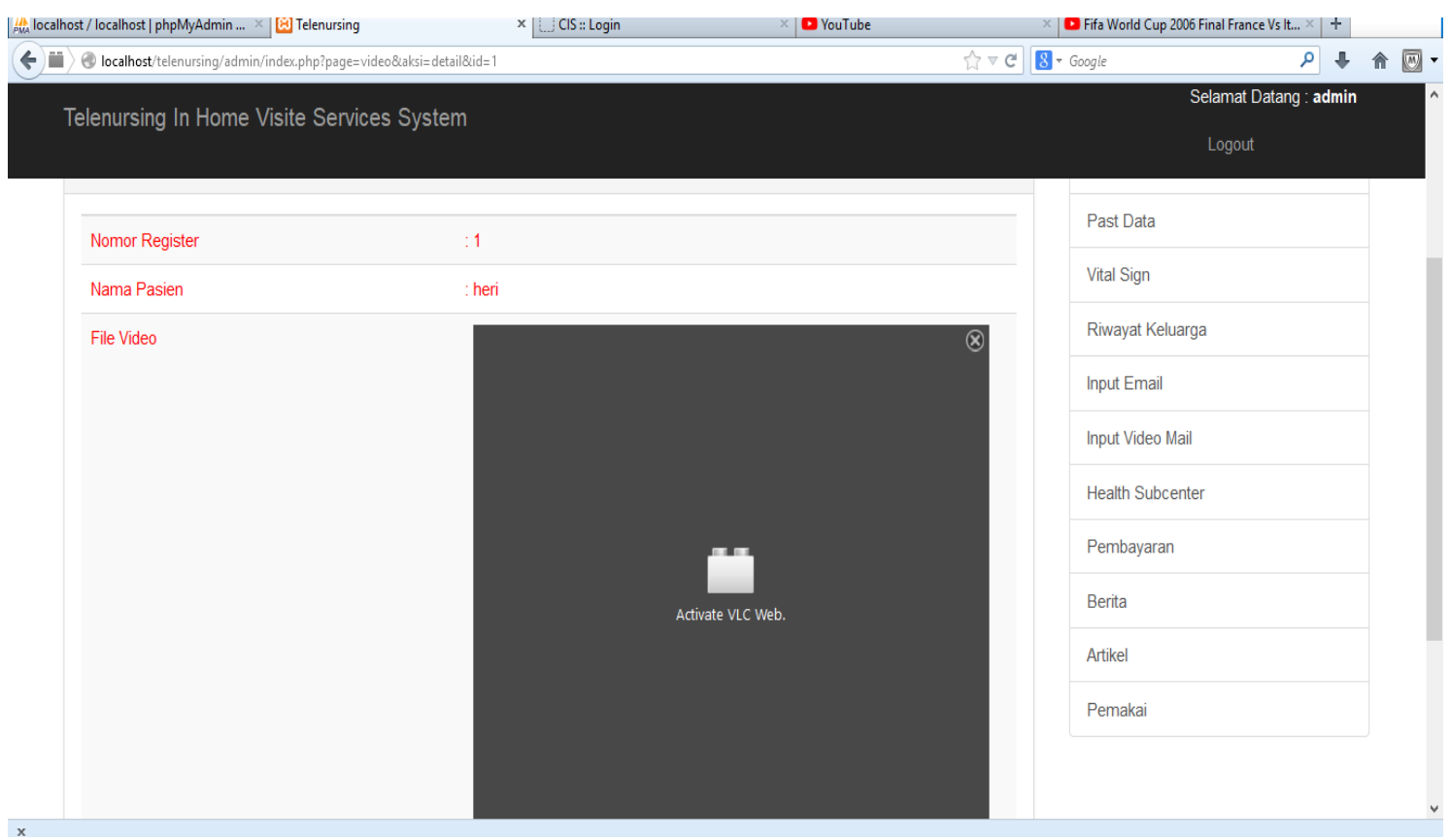

\section{Menu Health Subcenter}

Menu health subcenter berisi informasi jadwal perawat yang akan visit.

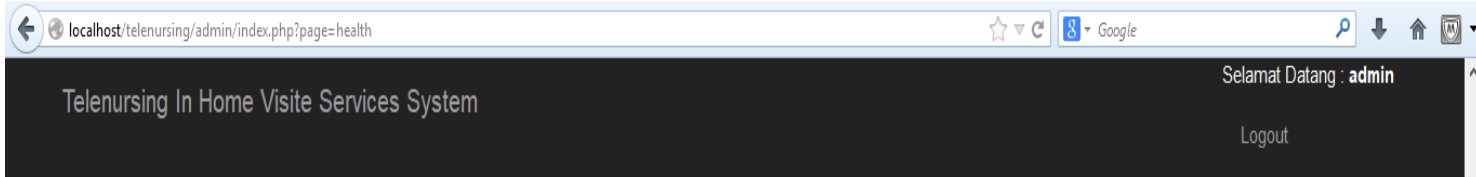

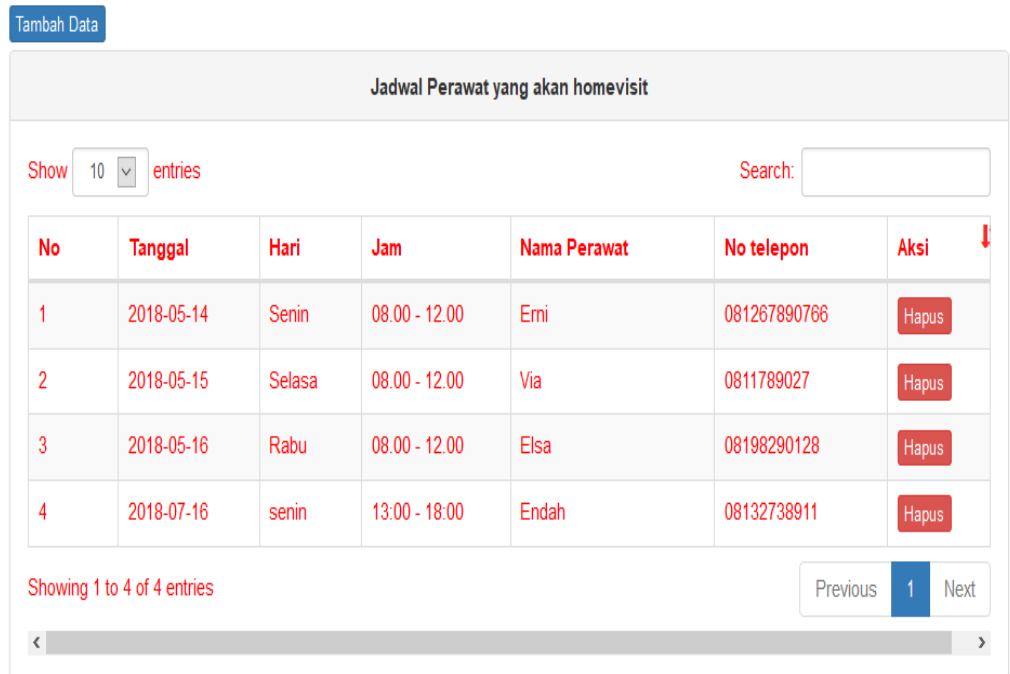

\section{Menu Pembayaran}

Menu pembayaran berisi daftar biaya yang harus dibayar oleh pasien. Pihak admin memasukkan jumlah biaya yang dikenakan kepada pasien, sekaligus untuk 
validasi bahwa pembayaran sudah lunas berdasarkan bukti pembayaran yang dikirim oleh pasien.

Pada saat input pembayaran pasien, status yang dipilih adalah belum lunas kemudian simpan. Setelah mendapatkan bukti pembayaran dari pasien baru diubah status menjadi lunas

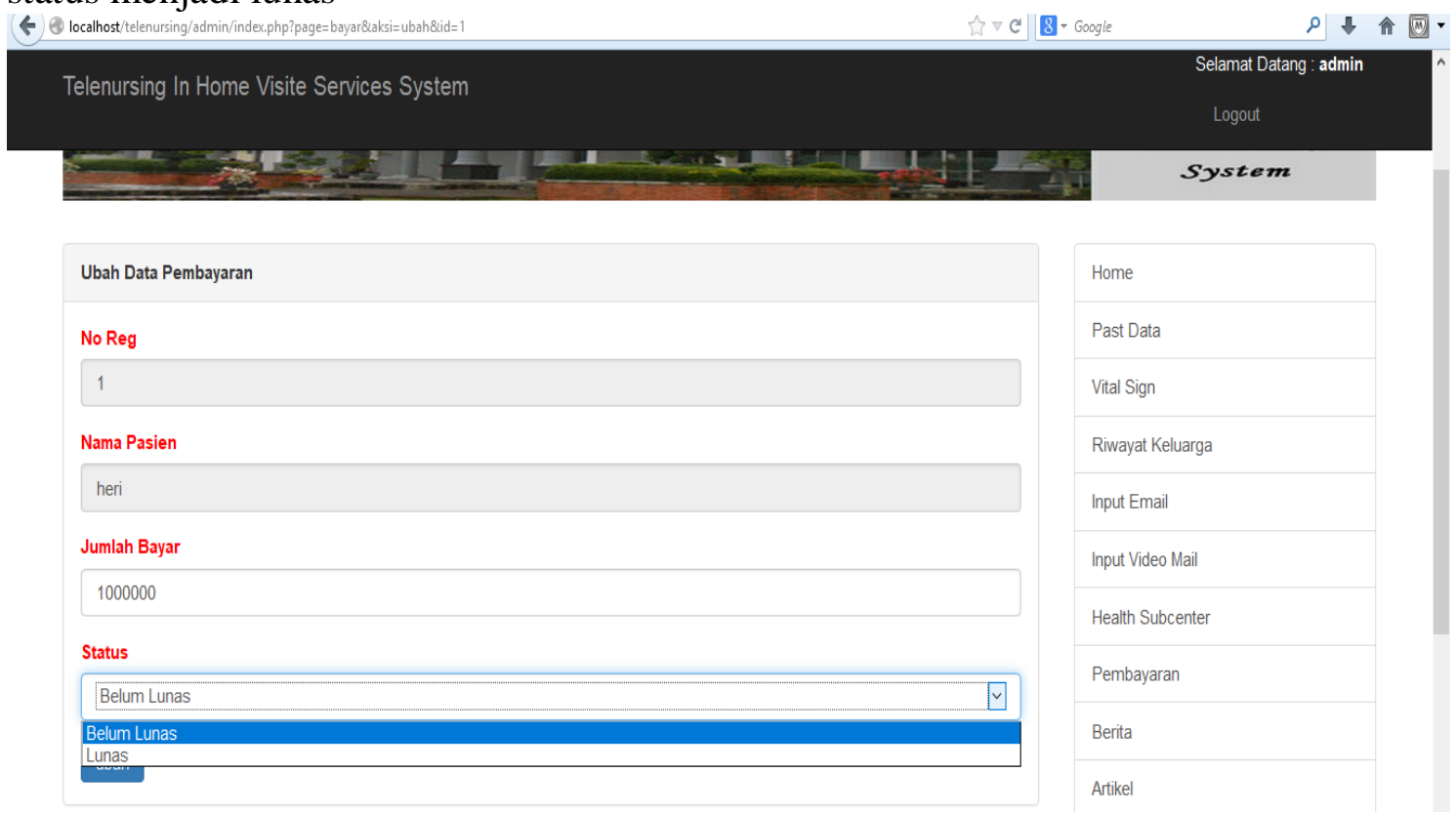

\section{Menu Berita}

Menu berita berisi form untuk menambahkan berita, edit berita dan hapus berita.

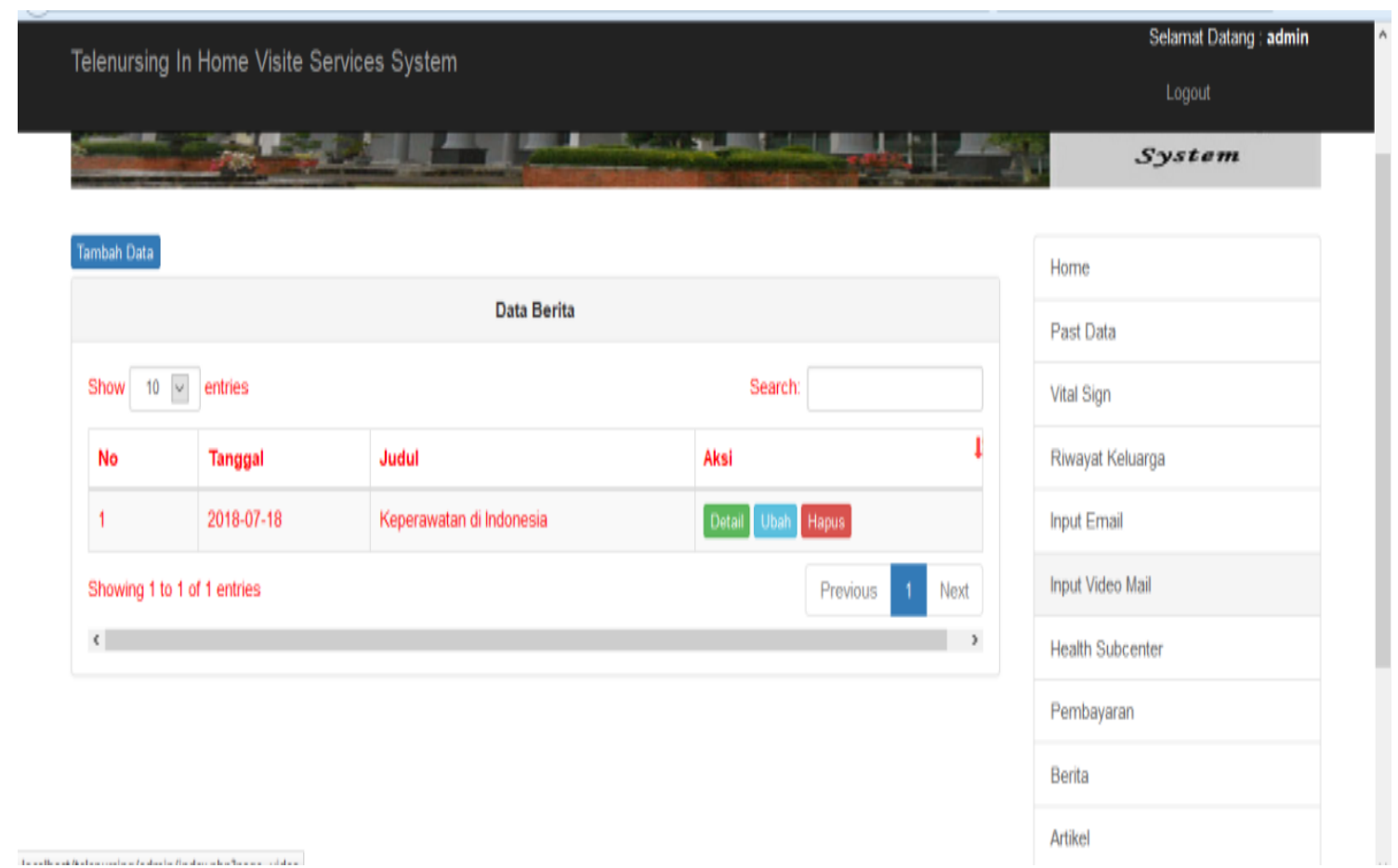




\section{Menu Artikel}

Menu berita berisi form untuk menambahkan artikel, edit artikel dan hapus artikel. Dalam form terdapat tanggal artikel, judul artikel danisi artikel.

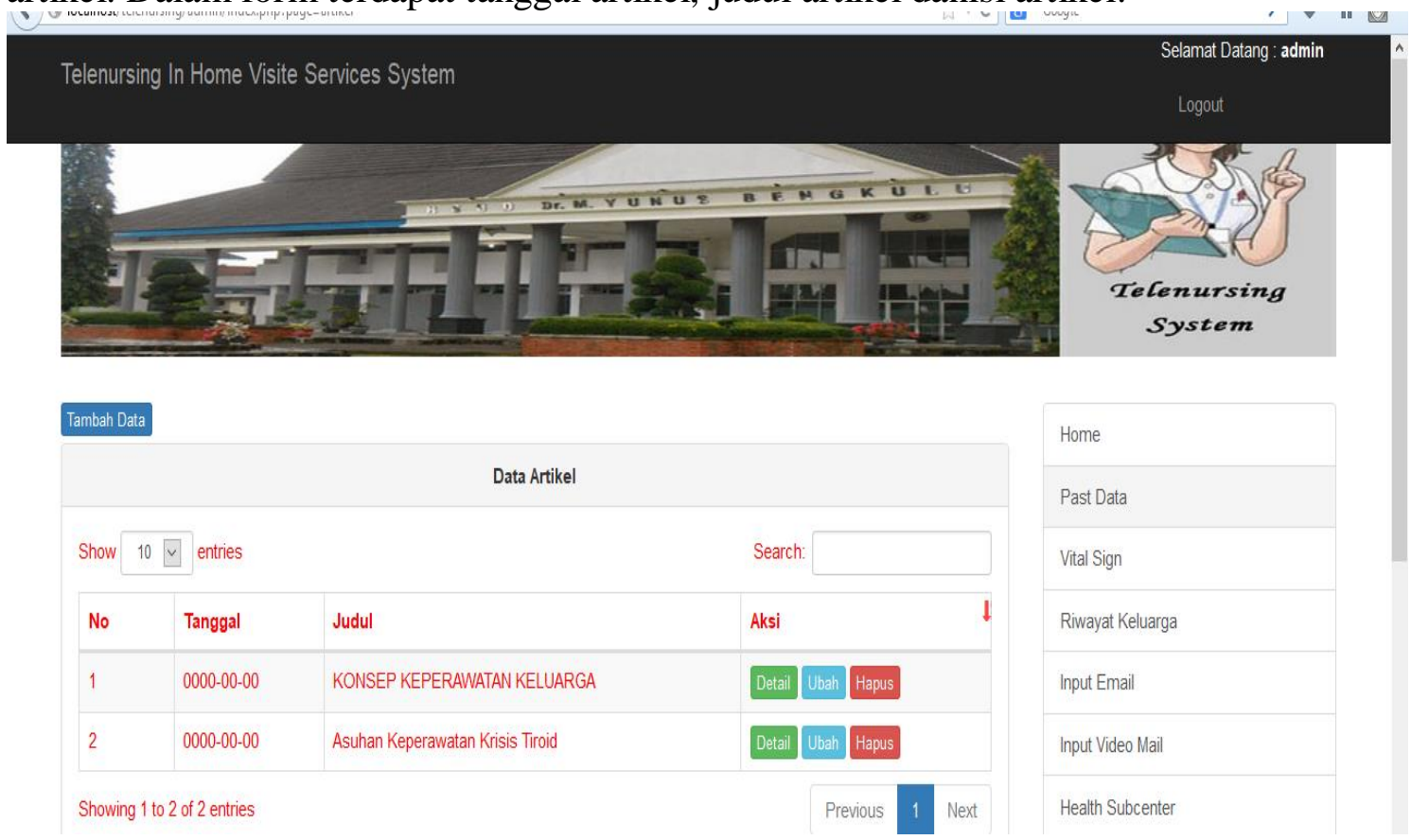

\section{Menu Pemakai}

Pada menu pemakai untuk membantu admin dalam mengelola pemakai system. Terdapat dua layanan yaitu sebagai admin dan sebagai pasien. Terdapat perbedaan saat login menggunakan admin dan menggunakan layanan pasien.

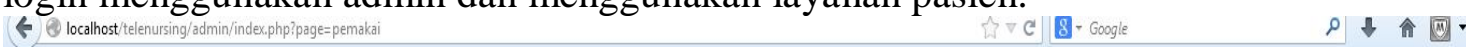
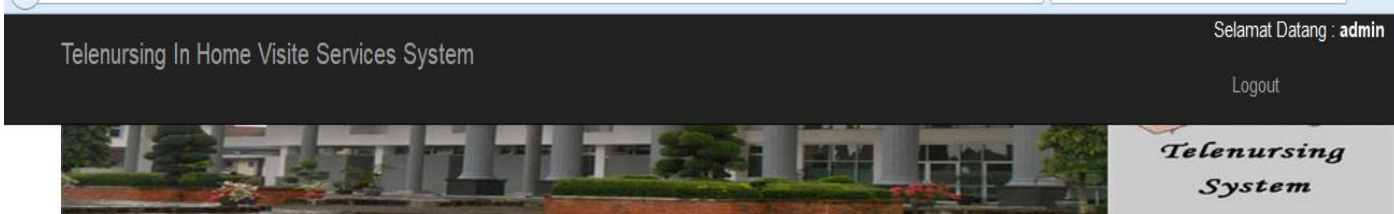

Tambah Data

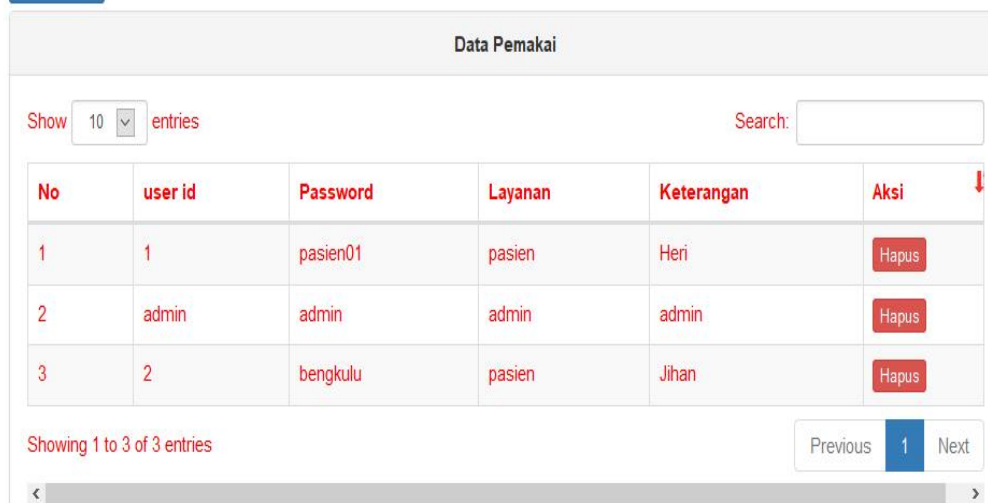

\begin{tabular}{l} 
Home \\
Past Data \\
Vital Sign \\
\hline Riwayat Keluarga \\
\hline Input Email \\
\hline Input Video Mail \\
\hline Health Subcenter \\
\hline Pembayaran \\
\hline Berita
\end{tabular}




\section{PEMBAHASAN}

Telenursing merupakan sistem pemberian pelayanan keperawatan yang efektif, dimanaia membuat pasien lebih mudah untuk mendapatkan informasi pelayanan keperawatan dan meningkatkan kemampuan pasien untuk merawat dirinya sendiri (Wikipedia, 2011). Selain itu telenursing juga membantu pasien dan keluarga untuk ikut berpartisipasi aktif dalam perawatan terutama self-management untuk penyakit kronis dan mengurangi lama perawatan (length of stay). Sistem ini memfasilitasi perawat memberikan informasi dan dukungan yang akurat secara online.

Tujuan dari SIM telenursing adalah tidak untuk membentuk diagnosis medis, melainkan difokuskan pada dimensi dari urgensi (Fairchild L.S, Elfrink V, Dieckman A, 2006). Sehingga para perawat akan lebih terfokus pada informasi, dukungan, dan meningkatkan pengetahuan. Untuk itu diperlukan komunikasi yang baik sehingga setiap perkataan akan mudah untuk didengar dan dipahami. Dengan demikian pasien dan keluarganya akan termotivasi untuk mengikuti saran perawat. Sebuah komunikasi yang berpusat pada pasien adalah teknik pendekatan yang disukai dalam rangka membina hubungan antara pasien dan tenaga professional (Hartford Kathleen, 2005). Komunikasi yang berpusat pada pasien telah ditangani secara ekstensif selama dekade terakhir (Chamber, P, 2009).

Hasil penelitian ini tersedianya sistem informasi manajemen berbasis home visit telenursing di RSUD Dr. M. YUNUS yang bertujuan melakukan monitoring, pendidikan, follow up, pengkajian dan pengumpulan data, melakukan intervensi, memberikan dukungan pada keluarga dan perawatan multidisiplin yang inovatif serta kolaborasi, terdiri dari 10 menu diantaranya adalah : a) Program login admin telenursing, b) Tampilan menu utama, c) database pusat data, d) databese vital sign, e) database riwayat keluarga, f) database input email, g) database video mail, h) database health subcenter (konsultasi), i) database pembayaran, h) database artikel, i) database berita, dan j) Logout. Menu-menu tersebut dapat diakses oleh pasien yang menjadi anggota SIM tersebut. Hasil penelitian ini selaras dengan hasil penelitian Jackson S, (2008) dimana perawat melakukan kegiatan perawatan seperti pengkajian, perencanaan, intervensi, dan evaluasi terhadap menggunakan teknologi seperti internet, computer, telephone, alat pengkajian digital, dan perlengkapan telemonitoring (Hartford Kathleen, 2005). System audio-vidio, satelit dan system komunikasi yang lain (Jackson S, 2008).

Hasil penelitian ini menggunakanalat bantu computer/laptop sebagai sarana teknologi informasi sehingga mampu menyediakan serta mensupport pasien dan perawat untuk saling memberikan informasi yang lebih efektif tanpa memikirkan jarak yang menjadi penghalang. Selain itu telenursing juga meningkatkan efektifitas dan efisiensi dalam pemberian pelayanan keperawatan di rumah (home care), karena telenursing merupakan salah satu program yang menyediakan perawat klinis melalui telekomunikasi kepada pasien di rumah. Teknologi ini juga memungkinkan tenaga kesehatan dan keperawatan profesional untuk tetap bisa memantau dari jarak jauh segala kondisi dan situasi pasien selama di rumah, khususnya kondisi yang mengarah pada keadaan abnormal. Untuk selanjutnya bisa menjadi pertimbangan untuk menentukan tindakan keperawatan dan kesehatan yang dibutuhkan oleh pasien apakah pasien tetap dirawat dirumah atau pasien harus dirujuk ke RS (Fairchild L.S, Elfrink V, Dieckman A, 2006; Wootton R., Patil N. g., Scoot R., E., Ho Kendall. 2009).

Kelebihan hasil penelitian SIM Telenursingini dari hasil telenursing sebelumnya adalah, SIM ini menambah menu artikel dan berita yang isinya tentang seputaran kesehatan yang dapat berganti setiap minggu atau setiap hari sesuai dengan kemapuan 
admin yang mengelolanya, sehingga dapat membuat pasienyang terhubung dengan SIM telenursing selalu membaca informasi-informasi terbaru yang akan meningkatkan pengetahuannya terhadap penyakit yang dirasakan, perkembangan penyakit saat ini, dan cara pencegahan penyakit, hal ini pula merupakan upaya preventif dan promotif bagi pasien sebelum penyakit menyebarluas, pasien juga merasa bahwa perawat telah meningkatkan perhatian tentang masalah kesehatan yang mereka rasakan sehingga pasien akan merasa lebih nyaman.

Selain itu kelebihan SIM ini adalah ia menambah menu konsultasi, dimana pasien yang telah menjadi anggota SIM telenursing ini, dimanapun bebas berkonsultasi apapun terkait masalah kesehatan ataupun seputar penyakityang dirasakan baik pasien maupun keluarga, berguna juga sebagai tempat untuk konsultasi tentang kesehatan, karena pasien akan lebih memilih cara ini dibandingkan dengan datang langsung berkunjung ke fasilitas kesehatan. Dengan pengembangan telenursing di bidang keperawatan yang mencakup tentang program pendidikan kesehatan (penkes) untuk pasien dan keluarga terutama tentang cara perawatan selama di rumah, maka akan meningkatkan kepuasan pasien dan keluarga tentang pelayanan keperawatan.

Penelitian ini juga langsung diujicobakan kepada masing-masing perwakilan perawata rawat inap yang berjumlah 15 orang perawat untuk memperoleh pemahaman perawat dalam penggunaan SIM telenursing. Kesimpulan yang didapat dari penelitian ini adalah antusiasme perawat dalam menerima tantangan baru dalam memberikan pelayanan telenursing sangat tinggi, hal tersebut dapat berdampak pada kemampuan meningkatkan komunikasi yang efektif antara perawat dan pasien. Perawatpun menjadi bertambah semangat dalam belajar meningkatkan kapasitas dirinya guna memberikan pelayanan keperawatan yang paripurna. Pemanfaatan telenursing perawat adalah bagian sentral dari penggunaan teknologi ini. Dengan demikian, telenursing bukan peran baru bagi perawat. Setiap perawat yang telah memberikan bimbingan atau pendidikan melalui komputerisasi/online berarti telah menggunakan telenursing.

Disamping itu peneliti membayangkan peran SIM telenursing ini menjadi sangat penting terutama bagi RS yang memiliki kekurangan tenaga perawat, yang tidak bisa meninggalkan ruangan disaat pasien membludak diruangan atau terjadinya kejadian luar biasa (KLB), bisa saja akan ada insiden dimana setiap ruangan menjadi krodit dan butuh bantuan banyak tim medis akan tetapi teman sejawat atau dokter tidak bisa keluar dari ruangan tersebut, atau bisa saja ada penyakit dengan virus terbaru yang mengaharuskan semua tenaga medis yang berdinas saat itu untuk diisolasi diruangan tersebut sehingga dokter dan tim medis lain tidak bisa masuk keruangan tersebut sampai hasil laboratoriumnya keluar, sehingga SIM inilah menjadi alat bantu komunikasi yang paling tepat dan fleksibel yang bisa menganalisis sesuatu kondisi pasien secara langsung meskipun tidak ditempat tersebut, SIM ini menjadi sangat penting dalam upaya koordinasi dan monitoring tindakan keperawatan dan medis yang bisa didapatkan melalui komunikasi pada SIM telenursing ini.

Dengan digunakan SIM telenursing ini di RS, tidak menutup kemungkinan income RS meningkat tajam, lalu akan menambah peningkatan gaji perawat dan tim medis lainnya sehingga akan meningkat pula produktivitas dalam bekerja. Seperti hasil penelitian Bohnenkamp \& Blackett meyatakan bahwa dengan perawat yang tergabung dalam telenursing menunjukkan kepuasan yang lebih tinggi daripada perawat yang tidak tergabung dalam pemberian perawatan telenursing, hal ini dikarenakan gaji yang diterima oleh perawat anggota telenursing menjadi lima kali lipat dari gaji perawat biasa (Graschew etall, 2008). 
Hal ini juga menuntut para perawat untuk terus meningkatkan keterampilan keperawatan dan tenaga medis dalam penggunaan perangkat lunak untuk mendukung SIM telenursing sebagai alat konsultasi jarak jauh menjadi lebih efisiensi dan tingkat kepuasan pasien terhadap layanan semakin meningkat sehingga tercapainya pelayanan prima di RS tersebut. Seperti hasil penelitian Jonsson \& Willman dalam penelitiannya menemukan bahwa implementasi telenursing dalam perawatan di rumah pada pasien dengan luka di tangan merupakan inovasi pengembangan inisiatif yang berfokus pada kolaborasi antara perawat dan pasien. Pasien merasa puas dengan penggunaan videophone untuk melihat staf perawat memberikan perawatan kepada mereka, dan dengan melihat muka perawat membuat rasa aman pada pasien. Perawat merasa lebih nyaman dengan penggunaan audio-vidio contact untuk melihat kondisi pasien dan melakukan pengkajian kondisi luka, serta merekam luka. Selain itu perawat merasakan bahwa waktu bekerja meraka lebih bermanfaat. Penelitian ini menandaskan bahwa telenersing dengan menggunakan teknologi audio-vidio sangat efektif untuk melakukan komunikasi antara perawat dan pasien dan memberikan kepuasan pada perawat dan pasien dalam melakukan perawatan rumah (Fairchild L.S, Elfrink V, Dieckman A. 2006; Yun E.K \& Park H.A. 2006).

Hal diatas selaras dengan pendapat yang di kemukakan oleh Johnsson A-M \& Willman A (2009) bahwasanya penggunaan komputer dan teknologi informasi untuk mensupport perawat dan pasien dengan informasi yang lebih efektif. Dalam rangka efisiensi dan efektifitas, antara perawat dan pasien terhubungkan secara langsung menggunakan system transmisi elektronik yaitu telenursing system. Begitu juga hasil penelitian dari Hartford Kathleen dalam penelitiannya tentang "Telenursing and patients' Recovery from Bypass" menemukan bahwa aplikasi teknologi telekomunikasi dalam memberikan pelayanan keperawatan membuat pasien mampu untuk belajar bagaimana merawat dirinya sendiri, dan ini juga membantu perawat untuk melakukan pendidikan kesehatan dan promosi kesehatan secara efektif. Selain itu juga memperpendek lama perawatan (Hartford Kathleen. 2005).

\section{Adapun Faktor-Faktor yang Mempengaruhi Implementasi Telenursing}

Ada empat faktor penting yang mempengaruhi implementasi telenursing menurut Yun E.K \& Park H.A. (2006), dan Hoglund A.T. (2007), empat faktor tersebut yaitu aspek sistematika, aspek ekonomi, aspek sosial, dan aspak teknikal. Aspek sistematika terkait dukungan dari pemerintah, yang meliputi legislasi dan regulasi. Dalam mengontrol kualitas dan kelangsungan telenursing sangat dibutuhkan pengaturan dan supervisi pelayanan pemerintah. Untuk penerapan telenursing disepakati bahwa praktek keperawatan mandiri seharusnya ada otoritas dan peraturan legal serta adanya standart operasional prosedur yang dibuat oleh organisasi profesi keperawatan atau pendidikan keperawatan.

Aspek ekonomi terkait verifikasi terhadap kontrol keuangan medis akibat penggunaan telenursing dan government recognition for cost effectiveness merupakan prioritas utama. Investasi pemerintah dalam proyek telenursing merupakan prioritas untuk megaktifkan telenursing di daerah rural dan area kepulauan untuk manfaat medis. Aplikasi system telenursing yang mahal dan uang perawatan (maintenance fee) harus dipikirkan (Barret, et.al 2009).

Aspek sosial terkait verifikasi nilai dan membangun kepercayaan sosial tentang telenursing dibandingkan dengan perawatan langsung. Penerimaan dari pemberi pelayanan kesehatan seperti fasilitas medis, dokter dan perawat, merupakan hal penting 
dalan implementasi telenursing. Kerja sama dan koordinasi antara profesi kesehatan akan membangun pemahaman yang lebih baik tentang telenursing pada publik. Adanya pengakuan publik terhadap keperawatan itu sendiri merupakan faktor kunci dalam pelaksanan telenursing.

Aspek teknikal terkait kreatifitas dan originalitas konten telenursing dan pengembangan sistem pelayanan. Pelatihan dan pendidikan perawat serta teknologi informasi mendukung pengembangan dan pengoperasian telenursing. Pengembangan teknologi informasi untuk menjaga privasi pasien dan keamanan informasi. Standarisasi, pelatihan keperawatan dan penelitian untuk pengembangan system telenursing dan pelaksanaannya, teknologi informasi medis dan pengembangan system aplikasi, serta desain model fungsional yang mungkin diterapkan dilingkungan tersebut. Jadi keempat aspek tersebut harus terintegrasi dalam strategi pelaksanaan telenursing (Johnsson A-M \& Willman A, 2009).

\section{Hambatan Implementasi Telenursing}

Menurut Amy Peck (2005) ada tiga ketegori dasar hambatan dalam telenursing, meliputi: perilaku, legislatif, dan teknologi. Hambatan perilaku, ada ketakutan bahwa perawat akan mendelegasikan tugas ke mesin. Pada awalnya perawat akan resisten terhadap telenursing akibat kurangnya penguasaan terhadap teknologi informasi dan teknologi telekomunikasi. Namun dengan adanya pelatihan dan adanya support system, perawat bisa merasakan manfaat telenursing untuk dirinya dan pasien. Legislasi, telenursing muncul sebagai issue kebijakan public secara mayor, belum adanya kepastian lisensi tentang telenursing. Secara teknologi, Elektronik Health Record (EHR) dan standar data mendukung perkembangan telenursing. Tanpa EHR telehealth tidak bisa bekerja. Ketersediaan system penyimpanan data pasien kapanpun dan dimanapun provider membutuhkannya (Johnsson A-M \& Willman A. 2008).

\section{SIMPULAN}

Home visit berbasis SIM telenursing di RSUD Dr. M. Yunus Bengkulu meliputi : a) Program login admin telenursing, b) Tampilan menu utama, c) database pastdata, d) databese vital sign, e) database riwayat keluarga, f) database input email, g) database video mail, h) database health subcenter, i) database pembayaran, h) database artikel, i) database berita, j) Logout.

Home visit berbasis sim telenursing dikembangkan secara online melalui website, dengan tahapan input, proses dan output (laporan)baik admin RS maupun pasien.

Telenursing menyediakan program perawatan profesional dengan layanan konsultasi, evaluasi, dan penelusuran pasti yang dapat meningkatkan aksesibilitas ke masyarakat yang menerima layanan medis atau informasi proses perawatan di tempattempat terpencil, meningkatkan saluran konsultasi dengan dokter, perawat, dan tenaga kesehatan lainnya dengan mengurangi waktu evaluasi yang panjang, dan meminimalkan pemindahan pasien dan informasi perawatan yang tidak perlu.

\section{SARAN}

Telenursing merupakan bagian dari telecare dengan menggunakan teknologi informasi, komunikasi, dan pemantauan yang memungkinkan penyedia layanan kesehatan untuk mengevaluasi status kesehatan secara jauh, memberikan intervensi pendidikan, atau memberikan perawatan kesehatan dan sosial kepada pasien di rumah mereka sudah seyogyanya diberlakukan dimasyarakat terutama rumah sakit yang 
menjadi rujukan sehingga menurunkan angka kesakitan dan meningkatnya derajat kesehatan dimasyarakat sehingga semakin bertambahnya angka harapan hidup di indonesia pada umumnya.

Didalam penerapan telenursing, keterampilan interpersonal sangat penting untuk mengamati dan mengidentifikasi kondisi fisik dan mental pasien secara lebih jauh dan memiliki kemampuan untuk memenuhi kebutuhan mereka sehingga pihak RS harus selalu memberikan pelatihan secara berkala bagi tenaga medis yang terlibat.

Layanan telenursing yang sukses memerlukan stabilitas teknis dan operasional harus memenuhi kebutuhan pasien. Tingkat kepercayaan yang diberikan terhadap telenursing oleh anggota keluarga yang menggunakan layanan telenursing menjadi faktor yang sangat penting. Kepercayaan keluarga merupakan faktor yang berpengaruh dalam menentukan apakah akan terus menggunakan layanan telenursing.

\section{DAFTAR PUSTAKA}

Barret. (2009). Challenges Faced in Implementation of a Telehealthenabled Chronic Woundcare System.The International Electronic Journal of Rural and Remote Health Research, Education, Practiceand Policy.ARHEN:http//www.rrh.org.au Diakses melalui www.proquest.com tanggal 29 Oktober2017

Borg \& Gall. (1983). Educational Research: An Introduction. Front Cover. Walter R. Borg, Meredith Damien Gall. Longman, Sixth Edition, New York: Longman

Cady. (2009). A Telehealth Nursing Intervention Reduces Hospitalizations in Children with Complex Health Condition. Journal ofTelemedicine and Telecare, 15, 317-320. Diakses melaluiwww.ebsco.com tanggal 29 September 2016s

Canadian Nurses Assosiation. (2015). Nurse One, the Canadian Nurses Portal Ottawa. Diperoleh melalui www.cna-alic.ca. Tanggal 24 Oktober2016

Canadian Nursing Informatics Assosiation. (2006).Satgger, Bragley-Thompsonquotes. Diperoleh melalui http://www.cnia.ca/about.htmTanggal 20 Oktober2016.Center for E-Health Nursing.2006. Diperoleh darihttp://www.Centerhealthnurse.com/centerhealth.html. Tanggal 21 Oktober2016

Chamber, P. (2009). Millenial Generation Nurses at Work Inteletriage. $A A A C N$ Viewpoint, 31, 12-14. Diakses melaluiwww.proquest.comtanggal 20 Oktober2017

Durrani, H \& Khoja. (2009). A Systematic Review of the Use of Telehealthinasian Countries. Journal of Telemedicine and Telecare, 15, 175-181.Diakses melalui www.proquest.com tanggal September2018

Fairchild L.S, Elfrink V, Dieckman A. (2006). Patient Safety, Telenursing and Telehealth. Available from: http://www.ncbi.nlm.nih.gov. ch48

Graschew. (2008). Network Design for Telemedicinee-Healthusing Satellite Technology. R. Latifi(Ed.):IOS Press. Diakses melalui www.ebsco.com tanggal 30 Oktober 2016

Hartford, K. (2005). Telenursing and Patients' Recovery from Bypass Surgery. Journal of Advance Nursing, 50(5), 459-468

Hibbert. (2004). Health professionals Responses to the Introduction of a Home telehealthservices. Journal of Telemedicine and Telecare, 10, 226-230. Diakses melalui www.ebsco.com tanggal 29 September2016

Hoglund, A.T. (2007). Ethical Dilemmas in Telenursing. Journal of Clinical Nursing, 16, 1865-1871. Available from: http:// www.crb. uu.se /research/clinicalethics/telenursing.html 
Jackson S. (2008). Technology Study Show Growing Use, Increase Satisfaction with Telehealth. Hospital Home Health, 25(5), 61-72. Available from: www.ahcmedia.com/online.html

Johnsson A-M \& Willman A. (2008). Implementation of Telenursing Within Home Health Care. Blekinge Institut of Tecnology. Sweden. Available from: http://www.bth.se

Johnsson A-M \& Willman A. (2009). Telenursing in Home Care Service of Registered Nurses. Electtronic Journal Of Health Informatics, 4(1), e9. Available from: http://www.ejhi.net

Kawaguchi. (2004). Development of a Telenursing System Forpatients with Chronic Condition. Journal of Telemedicine and Telecare, 10, 239-244. Diakses melalui www.ebsco.com tanggal 30 Oktober 2016

O'Connor. (2014). Health Professional's Response to the Introduction of a Home telehealthservices. Journal of Telemedicine and Telecare, 10, 239-244. Diakses melalui www.ebsco.com tanggal 30 Oktober 2016

Peck Amy. (2005). Changing The Face of Standard Nursing Practice Through Telehealth and Telenursing. Nurs Admin Q, 29(4), 339-343

Riskesdas., Balitbangkes., \& Kemenkes RI. (2016). Teknologi Informasi Pelayanan Kesehatan. Diakses Melalui www.edu.ac.id.Tanggal 20 Agustus 2017

Scotia. (2014). Telehealth Nursing. Journal of Telemedicine and Telecare, 10, 239-244. Diakses melalui www.ebsco.com tanggal 30 Oktober 2016

Wikipedia. (2011). Telenursing. dalam http://en.wikipedia.org/wiki/telenursing

Wootton R., Patil N. g., Scoot R., E., \& Ho Kendall. (2009). E-BOOK: Telehealth in the Developing World. Royal Society of Medicine Press Ltd. Nited Kingdom. Available From: http://www.rsmpress.co.uk

Yun E.K \& Park H.A. (2006). Factor Affecting The Implementation of Telenursing in Korea. College of Nursing, Seoul National University, Seoul, Korea. IOS Press

Yun. (2008). Critical to Quality in Telemedicine Service Management : Application of DFSS (Design For Six Sigma) and SERVQUAL. Diakses melalui www.ebsco.com tanggal 30 Oktober 2017 